\title{
Lusioersily
}

\section{Household slow sand filters in continuous and intermittent flows and their efficiency in microorganism's removal from river water}

\author{
Nasser Fava, N. D. M., Terin, U. C., Freitas, B. L. S., Sabogal-Paz, L. P., Fernandez-lbañez, P., \& Anthony \\ Byrne, J. (2020). Household slow sand filters in continuous and intermittent flows and their efficiency in \\ microorganism's removal from river water. Environmental Technology (United Kingdom), 1-10. \\ https://doi.org/10.1080/09593330.2020.1841834
}

Link to publication record in Ulster University Research Portal

Published in:

Environmental Technology (United Kingdom)

Publication Status:

Published online: 11/11/2020

DOI:

10.1080/09593330.2020.1841834

\section{Document Version}

Author Accepted version

\section{General rights}

Copyright for the publications made accessible via Ulster University's Research Portal is retained by the author(s) and / or other copyright owners and it is a condition of accessing these publications that users recognise and abide by the legal requirements associated with these rights.

\section{Take down policy}

The Research Portal is Ulster University's institutional repository that provides access to Ulster's research outputs. Every effort has been made to ensure that content in the Research Portal does not infringe any person's rights, or applicable UK laws. If you discover content in the Research Portal that you believe breaches copyright or violates any law, please contact pure-support@ulster.ac.uk. 
1 Drinking Water Treatment by Multistage Filtration on a Household Scale:

2 Efficiency and Challenges

3

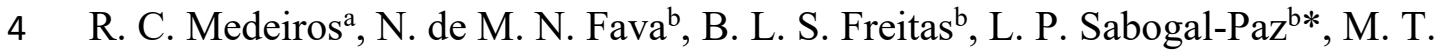

$5 \quad$ Hoffmann $^{\text {b; J. Davis }}{ }^{\mathrm{c}}$, P. Fernandez-Ibañez ${ }^{\mathrm{c}}$, J. A. Byrne ${ }^{\mathrm{c}}$

6

$7 \quad{ }^{a}$ Department of Engineering and Environmental Technology. Federal University of

8 Santa Maria. Zip Code: 98400-000. Frederico Westphalen - Rio Grande do Sul, Brazil.

9

10 b Department of Hydraulics and Sanitation, São Carlos School of Engineering,

11 University of São Paulo, Trabalhador São-Carlense Avenue, 400, São Carlos, São

12 Paulo, 13566-590, Brazil.

13

${ }^{\mathrm{c}}$ Nanotechnology and Integrated Bioengineering Centre, School of Engineering, Ulster

University, Jordanstown, BT37 0QB, Northern Ireland, United Kingdom

16

*Email:lysaboga@sc.usp.br

Universalising actions aimed at water supply in rural communities and indigenous populations must focus on simple and low-cost technologies adapted to the local context. In this setting, this research studied the dynamic gravel filter (DGF) as a pre-treatment to household slow-sand filters (HSSFs), which is the first description of a household multistage filtration scale to treat drinking water. DGFs (with and without a non-woven blanket on top of the gravel layer) followed by HSSFs were tested. DGFs operated with a filtration rate of $3.21 \mathrm{~m}^{3} \cdot \mathrm{m}^{-2} \cdot \mathrm{d}^{-1}$ and 
HSSFs with $1.52 \mathrm{~m}^{3} \cdot \mathrm{m}^{-2} \cdot \mathrm{d}^{-1}$. Influent water contained kaolinite, humic acid and suspension of coliforms and protozoa. Physical-chemical parameters were evaluated, as well as Escherichia coli, Giardia spp. cysts and Cryptosporidium spp. oocyst reductions. Removal was low (up to 6.6\%) concerning true colour, total organic carbon and absorbance $(\lambda=254 \mathrm{~nm})$. Nevertheless, HMSFs showed turbidity decrease above $60 \%$, E. coli reduction up to $1.78 \log$, Giardia cysts and Cryptosporidium oocysts reductions up to $3.15 \log$ and $2.24 \mathrm{log}$, respectively. The non-woven blanket was shown as an important physical barrier to remove solids,

Keywords: drinking water; low-cost technology; slow sand filtration; protozoa; Escherichia coli.

Abbreviations:

DGF: dynamic gravel filter

HMSF: household multistage filter

HSSF: household slow-sand filter

SSF: slow sand filtration

MSF: multistage filtration

VSS: volatile suspended solids 
According to Sustainable Development Goal 6, the aim is to achieve universal and equitable access to safe drinking water, sanitation and hygiene, particularly for the poorest and most vulnerable communities by 2030 (WHO and UNICEF, 2017). Inadequate sanitation produces millions of waterborne diseases (Perez et al., 2012) and the higher risks are for children living in low- and middle-income countries (Speich et al., 2016). Clearly, there are large gaps between urban and rural coverage of drinking water and sanitation services in these areas (WHO and UNICEF, 2017). In this context, Efstratiou et al. (2017) emphasised that Giardia cysts and Cryptosporidium oocysts were the main causes of waterborne outbreaks worldwide.

Decentralised water treatment is crucial in improving the drinking water consumed by the poorest population (Baig et al., 2011). The WHO recommended household water treatment as a way to increase access to safe water for people, who live in rural areas in developing countries (WHO, 2011).

Household slow sand filters (HSSFs) are highlighted as a technology for drinking water treatment in rural communities. HSSFs can promote effective removal of pathogens and particulate matter. Its simple design, easy and cheap construction, operation and maintenance may contribute to improving life quality in rural communities (Manz, 2007).

The main HSSF mechanisms to remove microbiological and physicochemical parameters are filtration, adsorption and microbiological activity (Jenkins et al., 2011). Helminths and particulate matter removal are due to trapping in the pores between sand grains and attachment to the surfaces of the sand grains (Jenkins et al., 2011; Manz, 2007). There are studies that have reported bacteria, viruses and protozoa reductions, as 
well as cyanobacteria, cyanotoxins and turbidity removals (Elliott et al., 2011; Terin and Sabogal-Paz, 2019; Wang et al., 2014). Clasen et al. (2015) reported that HSSF reduced $50 \%$ of diarrhoea cases in children.

Recently, HSSFs have been optimised by using new materials, sand bed depth reduction, different sand sizes and filter ripening ways, adding non-woven blankets to the top layer and operation in continuous and intermittent flows (Calixto et al., 2020; Elliott et al., 2008; Faria Maciel and Sabogal-Paz, 2018; Napotnik et al., 2017; Souza Freitas and Sabogal-Paz, 2019; Young-Rojanschi and Madramootoo, 2014). HSSFs have limitations that are analogous to conventional slow filters when removing solids and organic compounds. The excess of suspended material in the influent water obstructs the intergranular voids causing a reduction in the filter run and an increase in cleaning activities (Souza Freitas and Sabogal-Paz, 2019). Therefore, coarse media filtration could be used as a pre-treatment, creating the multistage filtration (Galvis et al. 2002). There should be more than one treatment stage, within the multi-barrier concept, which would act in the gradual removal of fine particles and microorganisms in order to produce safe water (Visscher, 2006). Consequently, prefiltration with coarse gravel (when included) would make the HSSF more efficient when turbid water is treated.

In this context, the aims of this study were to evaluate the HMSF performance to remove physicochemical and microbiological parameters from influent water with high levels of colour and turbidity.

\subsection{HMSF Construction}



$1)$.

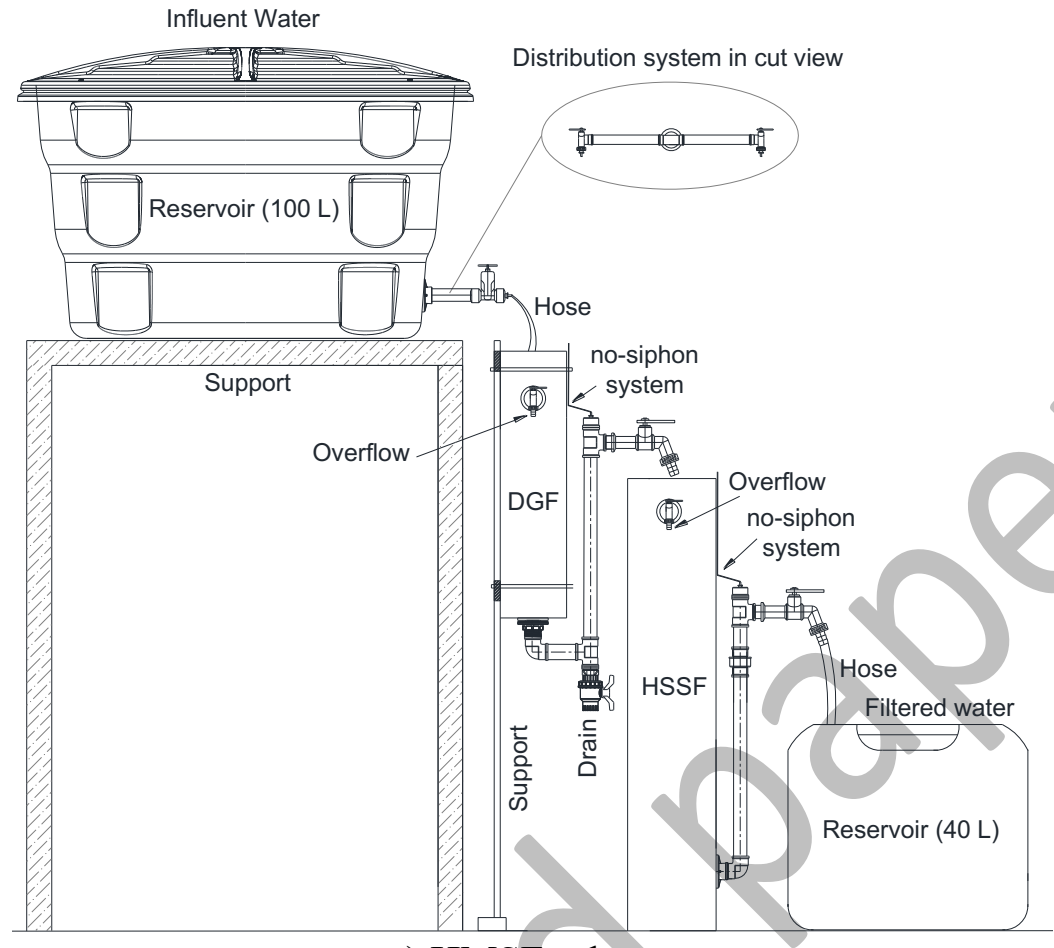

a) HMSF scheme

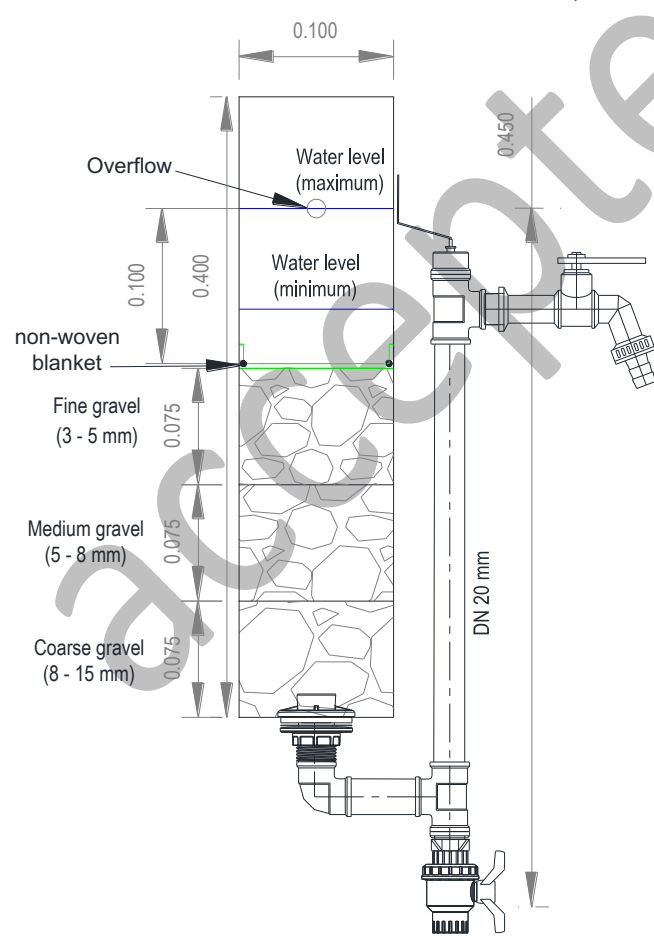

b) DGF scheme (units in meters)

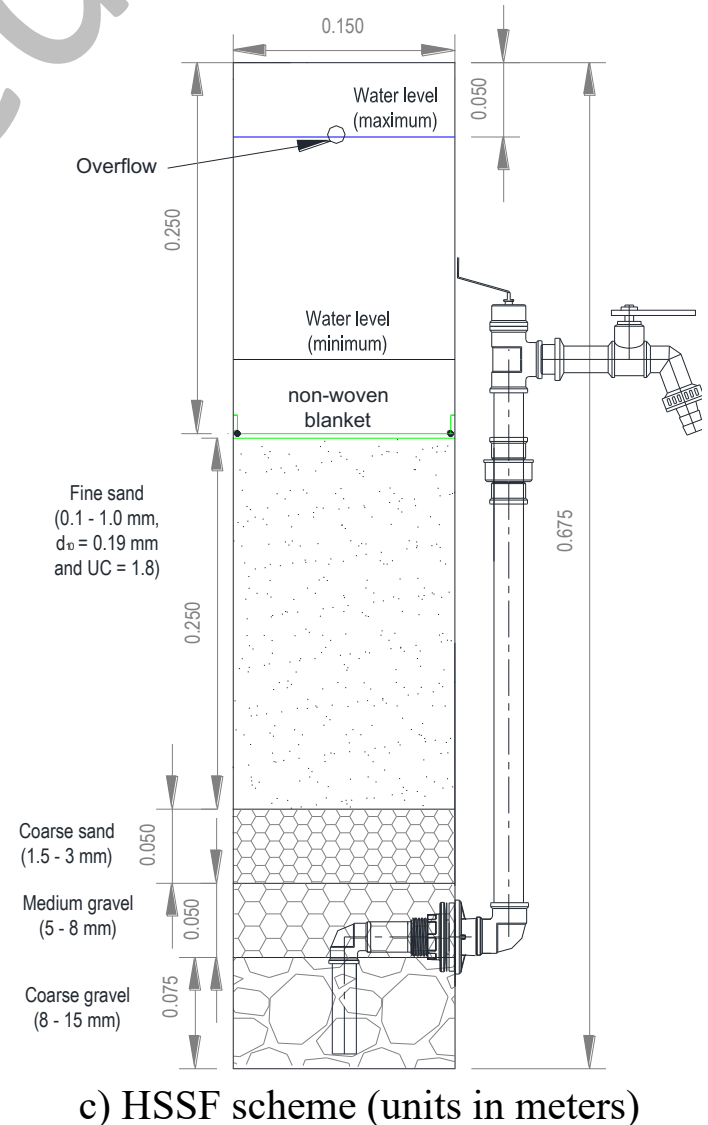

98 Figure 1. HMSF with a dynamic gravel filter (DGF) as a pre-treatment of an HSSF 
blanket on top of the gravel layer) was followed by HSSFs. DGFs were constructed in

PVC pipes with a $99.8 \mathrm{~mm}$ inside diameter (cross-sectional area $\left.=0.0078 \mathrm{~m}^{2}\right) . \mathrm{DGF}$

was filled with three gravel layers of $7.5 \mathrm{~cm}$ thickness each (coarse gravel with 8.0 to 15 $\mathrm{mm}$, medium gravel with 5.0 to $8.0 \mathrm{~mm}$ and fine gravel with 3.0 to $5.0 \mathrm{~mm}$ ). HSSFs were equally built out of PVC with $145 \mathrm{~mm}$ inside diameter (cross-sectional area $=$ $0.0164 \mathrm{~m}^{2}$ ) and they were filled with two gravel layers which worked as support media (sizes: 5 to $8 \mathrm{~mm}$ and 8 to $15 \mathrm{~mm}$ ) followed by a coarse sand layer (1.5 to $3.0 \mathrm{~mm}$ ) and days and during this period, two stops in the filter operation took place, one lasting 19 days and the other 14 days. The stops were purposeful in order to assess what would 


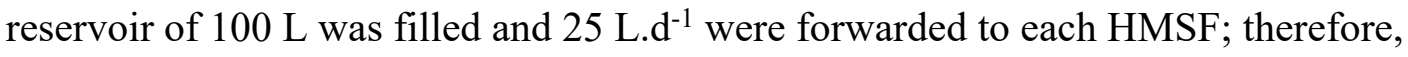
there was a declining filtration rate and valves were calibrated daily for each HMSF. Filter head loss was evaluated every other day and the HMSF stopped for maintenance when the flow rate was less than $25 \mathrm{~L} \cdot \mathrm{d}^{-1}$.

\subsection{HMSF maintenance}

the cleaning liquid was stored for physicochemical and microbiological analysis. The same procedure was followed with the fluid drained from each DGF. Blankets were removed from each HSSF and the biological layer (schumutzdecke) was removed by splashing deionised water. The sand top was agitated manually three times and after was left steady for $1.0 \mathrm{~min}$ for sedimentation, then the supernatant was removed and stored for analysis as well.

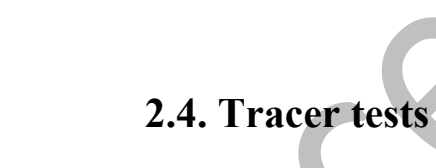

Tracer tests were performed three times prior to HMSF operation. A solution of $100 \mathrm{mg} \cdot \mathrm{L}^{-1}$ of $\mathrm{NaCl}$ was used as the tracer. A 100-L reservoir was filled with saline solution and a submersible water pump HM-5063 (Jeneca®, China) was placed for homogenisation to take place. A conductivity probe (Vernier ${ }^{\circledR}$ Software \& Technologies, USA) with a Go!link ${ }^{\circledR}$ interface was positioned at an outlet pipe and the data was collected by Logger Lite ${ }^{\circledR}$ software (Vernier Software \& Technologies, USA).

148 The tracer test was carried out until the salt solution was close to $100 \mathrm{mg} . \mathrm{L}^{-1}$ in the filter 
output. Microsoft Excel ${ }^{\circledR}$ was used to develop the normalisation curve of tracer concentration over time and Origin $8.6{ }^{\circledR}$ (Originlab, EUA) was used for data analysis resulting in the residence time distribution curve. Mean residence times in each filter were determined and the flow pattern was adjusted according to three hydrodynamic mathematical models (low dispersion, high dispersion and $\mathrm{N}$-continuous stirred tank reactors) as recommended by Levenspiel (1999).

\subsection{Influent Water}

Influent water was a mixture of well water, $60 \mathrm{mg} \cdot \mathrm{L}^{-1}$ of kaolinite (Sigma Aldrich $\left.{ }^{\circledR}\right), 20 \mathrm{mg} . \mathrm{L}^{-1}$ of humic acid (Sigma Aldrich $\left.{ }^{\circledR}\right)$ and Escherichia coli (ATCC 11229) which were agitated for $30 \mathrm{~min}$ by a mechanical mixer. Influent water was prepared to reach similar characteristics of challenge test water used for validating drinking water technologies, as described in WHO (2014). Well water and influent water characteristics are shown in Table 1.

Table 1 - Well water and influent water characteristics for the study

\begin{tabular}{lcc}
\hline Parameter & \multicolumn{2}{c}{ Mean \pm Standard deviation } \\
\cline { 2 - 3 } & Well water & Influent water \\
\hline $\mathrm{pH}$ & $6.24 \pm 0.33$ & $7.65 \pm 0.15$ \\
\hline Temperature $\left({ }^{\circ} \mathrm{C}\right)$ & $22.7 \pm 1.7$ & $22.7 \pm 0.8$ \\
\hline Total Alkalinity $\left(\mathrm{mg} \mathrm{CaCO}_{3} \mathrm{~L}^{-1}\right)$ & $26.4 \pm 3.8$ & $34.03 \pm 8.31$ \\
\hline Conductivity $\left(\mu \mathrm{S} \mathrm{cm}^{-1}\right)$ & $59.7 \pm 6.7$ & $68.1 \pm 6.7$ \\
\hline True Colour $(\mathrm{HU})$ & $3.2 \pm 3.6$ & $246 \pm 22$ \\
\hline Apparent Colour $(\mathrm{HU})$ & $1.8 \pm 2.8$ & $338 \pm 36$ \\
\hline Turbidity $(\mathrm{NTU})$ & $0.177 \pm 0.091$ & $42 \pm 16.7$ \\
\hline Absorbance $(\lambda=254 \mathrm{~nm})$ & $0.015 \pm 0.031$ & $0.554 \pm 0.101$ \\
\hline Total organic carbon $-\mathrm{TOC}\left(\mathrm{mg} \mathrm{L}^{-1}\right)$ & $3.13 \pm 3.95$ & $7.63 \pm 0.71$ \\
\hline Particle size $(\mathrm{nm})$ & Not analysed & $1116 \pm 317$ \\
\hline Escherichia coli $\left(\mathrm{CFU} 100 \mathrm{~mL}^{-1}\right)$ & 0 & $1.03 \times 10^{5}$ \\
\hline
\end{tabular}


Total coliforms (CFU $\left.100 \mathrm{~mL}^{-1}\right) \quad 0.2 \pm 0.4 \quad 0$

After 53, 64 and 88 days of continuous operation, approximately $10^{3}$ cysts of

Giardia lamblia and $10^{2}$ oocysts of Cryptosporidium parvum from purified suspensions

169

170

171

172

173

174

175

(Waterborne ${ }^{\circledR}$ Inc, USA) were added to the DGFs and HSSF inlets. In these three assays, cysts and oocysts were added over four consecutive days prior to protozoa analysis. Between the $101^{\text {st }}$ and $140^{\text {th }}$ days of continuous operation, cysts and oocysts were added daily and four protozoa analyses were performed.

\subsection{Sampling and analysis}

Temperature, $\mathrm{pH}$, turbidity, apparent colour, true colour, absorbance $(\lambda=254$ $\mathrm{nm}$ ), total alkalinity, conductivity, particle size, total organic carbon (TOC), E. coli and total coliforms were analysed according to APHA et al. (2012).

\subsubsection{Protozoa analysis}

Protozoa protocols included membrane filtration and triple centrifugation.

Filtration with cellulose mixed ester membranes $(47 \mathrm{~mm}$ diameter and $3 \mu \mathrm{m}$ nominal porosity, Millipore $\left.{ }^{\circledR}\right)$ was performed according to Franco et al. (2016) without immunomagnetic separation (IMS). Samples from DGFs and HSSFs were filtered until reaching the number of five ester membranes used. Cysts and oocysts were eluted by scraping the membrane three times using Tween $80\left(0.1 \%, 45^{\circ} \mathrm{C}\right)$. Samples were kept in $50 \mathrm{~mL}$ Falcon tubes for centrifugation at 1,500 $\mathrm{g}$ for $15 \mathrm{~min}$. Supernatant was discarded until the pellet was $5 \mathrm{~mL}$, and then it was mixed for homogenisation. After 
another centrifugation $(1,500 \times \mathrm{g} ; 15 \mathrm{~min})$, the supernatant of each sample was discarded until $1 \mathrm{~mL}$ pellet was left for analysis.

Samples from the non-woven blanket cleaning water, the DGF drain and the HSSF biological layer were concentrated by triple centrifugation at 1,500 $x \mathrm{~g}$ for 15 min, following the Medeiros and Daniel (2018) protocol. Samples were kept in $50 \mathrm{~mL}$ Falcon tubes for centrifugation at 1,500 $\times \mathrm{g}$ for $15 \mathrm{~min}$. Afterwards, the supernatant was removed until $5 \mathrm{~mL} .10 \mathrm{~mL}$ of elution solution (Tween 80, 0.1\% v/v) was added and mixed by 30s. Centrifugation was performed again and the supernatant was removed, $10 \mathrm{~mL}$ of deionised water were added and, after mixing, a third and last centrifugation was done. The remaining $5 \mathrm{~mL}$ were stored overnight in a refrigerator. The final pellet was vortexed and the Dynabeads ${ }^{\mathrm{TM}}$ GC-Combo (TermoFisher Scientific ${ }^{\circledR}$ ) manufacturer's protocol was followed to perform immunomagnetic separation (IMS). Two acid dissociations were carried out to increase cyst and oocyst recoveries, according to Method 1623.1 (USEPA, 2012).

Protozoa detection for both methods (membrane filtration and triple centrifugation) was performed by immunofluorescence assay (IFA) using the Merifluor ${ }^{\circledR}$ kit (Meridian Bioscience Diagnostics, USA), following the manufacturer's protocol and Method 1623.1 (USEPA, 2012). Sample observations were made using an epifluorescence microscope (Olympus ${ }^{\circledR}$ BX51). Cysts and oocysts were identified by their size, morphology, shape and fluorescence and their concentration per litre was calculated according to Method 1623.1 (USEPA, 2012) in filtered water. Protozoa concentration per gram of total solids (referring to $50 \mathrm{~mL}$ of sample) was calculated for samples obtained from non-woven blanket cleaning, DGF drain and the HSSF biological layer. 
method to verify how the matrix would influence protozoan recovery. The assays were approximately 3,000 Giardia cysts and 300 Cryptosporidium oocysts extracted from purified suspensions purchased from Waterborne ${ }^{\circledR}$ Inc, USA. Moreover, $15 \mu \mathrm{L}$ of purified Cryptosporidium oocyst suspension and $5 \mu \mathrm{L}$ of Giardia cysts were evaluated in triplicate to estimate the mean number of inoculated organisms in the matrix. were spiked with cysts and oocysts and mixed with magnetic stirring for 2 min. After this period, the method explained above was followed.

For the triple centrifugation method with IMS, a sample of the drainage liquid from DGF was utilised since it showed turbidity and colour similar to the HSSF biological layer and non-woven blanket cleaning samples. In this case, a $25 \mathrm{~mL}$ sample was disposed into $50 \mathrm{~mL}$ Falcon tubes and cysts and oocysts were inoculated. Falcon tubes were mixed for 30 s and they were filled again with the sample upon reaching 50 $\mathrm{mL}$. A final mixture lasting 30 s was performed on the sample before starting the method described above. Recovery (R\%) for each protocol was calculated by Equation 1.

\subsection{Microorganisms present in the non-woven blanket} was carried out under a microscope (Olympus ${ }^{\circledR}$ BX60) at 100x to 2000x magnification. 
Samples of each used blanket (DGF1 and HSSFs) and new blanket (blank test) were analysed by a Scanning Electron Microscope (SEM), (Zeiss ${ }^{\circledR}$ LEO 440) to capture photomicrographs at 300 to $10,000 \mathrm{x}$ magnification.

\subsection{Statistical analysis}

Statistica ${ }^{\circledR} 7.0$ (StatSoft, Inc, 2004) was used for statistical analysis. The

Shapiro-Wilk test was applied in order to verify data normality. Comparisons between DGFs, HSSFs and HMSFs were made by the Student's t-test and Tukey test for multiple comparisons. When data, even after transformation, did not present normality, we resorted to the Mann-Whitney U test. There was a study of Pearson's correlation (parametric data) and Spearman's (non-parametric data) correlation between physical and operating variables and E. coli and protozoa reductions. P-values less than 0.05 were considered significant.

\section{Results and Discussion}

\subsection{Tracer Tests}

Tracer test results for the four filters are shown in Figure 2. The N-CSTR model offered the best fit to all of the filter data, considering Pearson's correlation coefficient $\left(\mathrm{r}^{2}\right)$ : DGF1 (0.93); DGF2 (0.91); HSSF1 (0.99) and HSSF2 (0.99). Therefore, the numbers of reactors in series were $9 \pm 2$ for DGF1, $8 \pm 2$ for DGF2, $8 \pm 2$ for HSSF 1 and $7 \pm 0.1$ for HSSF2, closer to the plug flow reactor, according to Levenspiel (1999). A similar performance was described by Faria Maciel and Sabogal-Paz (2018), Terin and Sabogal- 
264 Paz (2019) and Sabogal-Paz et al. (2020), characterising a plug flow reactor for the HSSF as well.
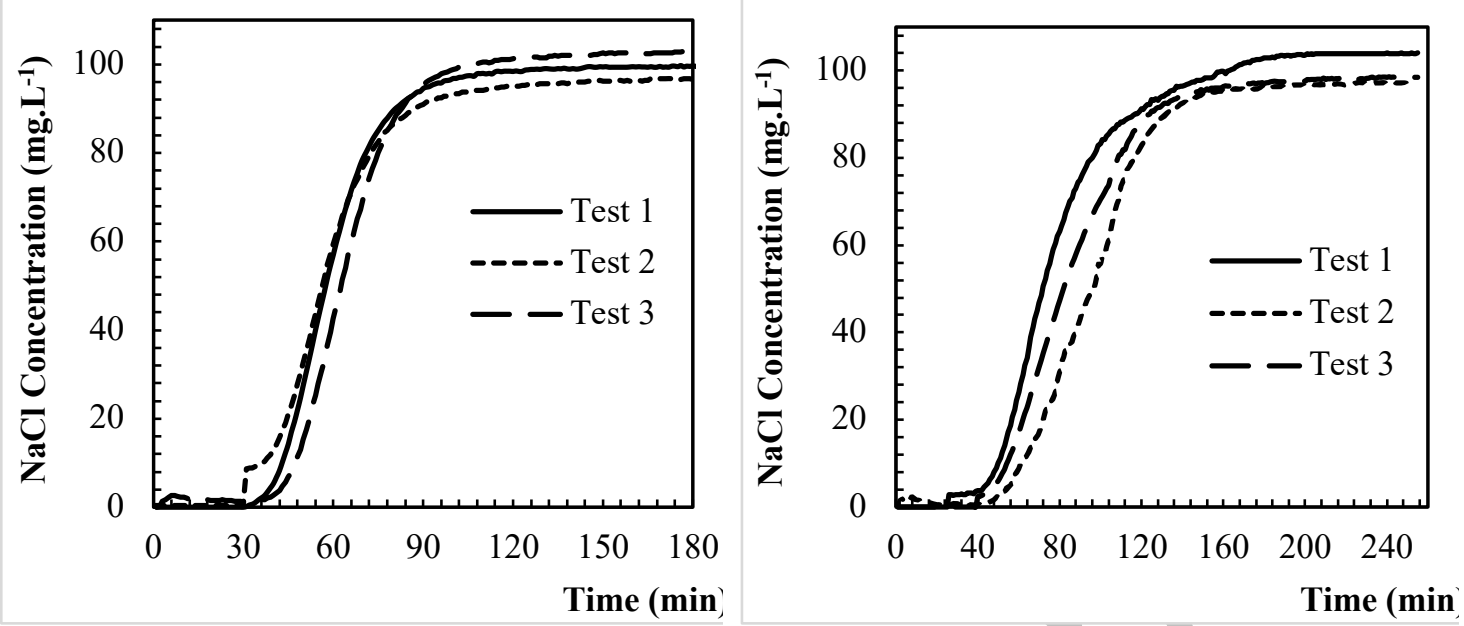

a) DGF 1

b) DGF2
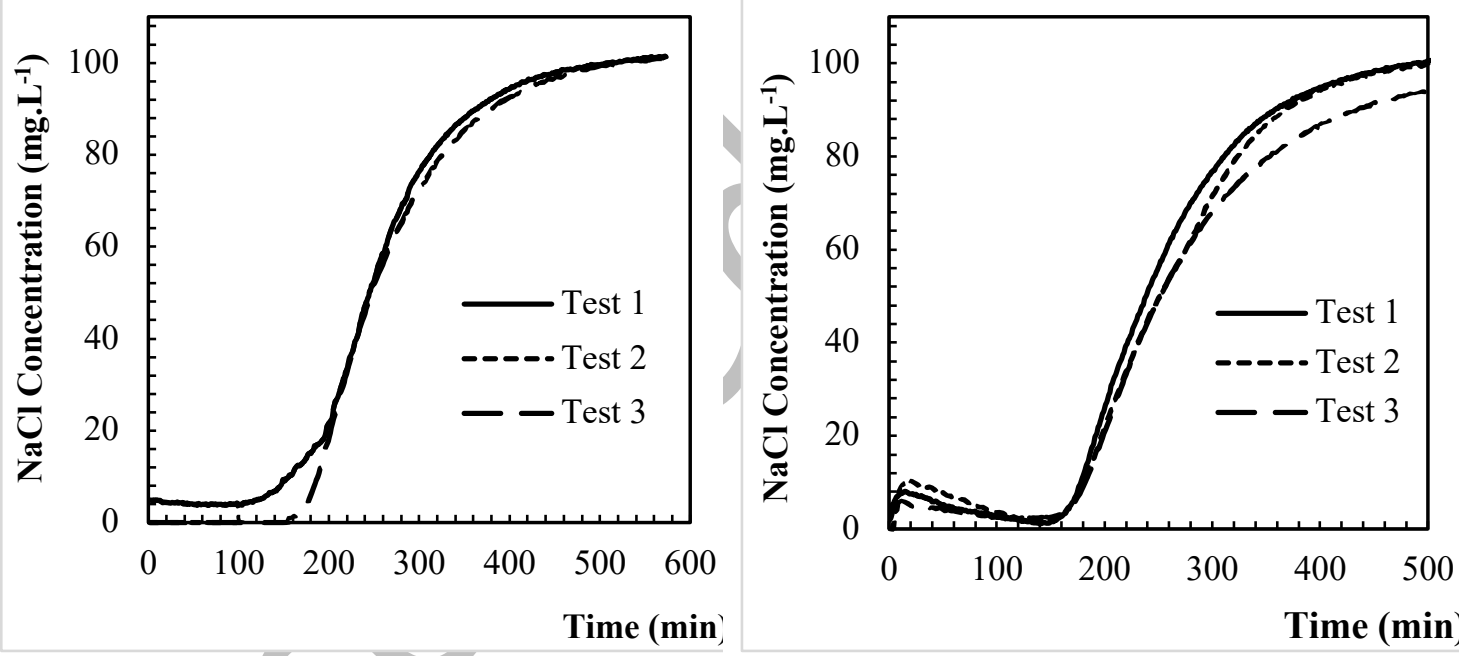

c) HSSF1

d) HSSF2

266

267 Figure 2 - Tracer tests results in triplicate

268

Mean residence times used for estimating the sampling times were $61 \pm 4 \mathrm{~min}$

270 for DGF1, $86 \pm 7 \mathrm{~min}$ for DGF2, $258 \pm 8 \mathrm{~min}$ for HSSF1 and $261 \pm 3 \mathrm{~min}$ for HSSF2.

271 HSSF flow characterisation is an important operational parameter (e.g. it can define the

272 water sampling time) and few studies have considered this aspect (Sabogal-Paz et al.

$2732020)$. 
275 Filtered water features and HMSF efficiencies (DGF+HSSF) are shown in Table 2.

276 Table 2. Filtered water characteristics for each filter and HMSF efficiencies

\begin{tabular}{|c|c|c|c|c|}
\hline \multirow{2}{*}{ Parameter } & \multicolumn{4}{|c|}{ Mean \pm Standard deviation (SD) } \\
\hline & DGF1 & HSSF1 & DGF2 & HSSF2 \\
\hline $\mathrm{pH}$ & $7.59 \pm 0.11$ & $7.61 \pm 0.09$ & $7.58 \pm 0.12$ & $7.62 \pm 0.08$ \\
\hline Temperature $\left({ }^{\circ} \mathrm{C}\right)$ & $22.4 \pm 0.6$ & $22.4 \pm 0.7$ & $22.4 \pm 0.6$ & $22.3 \pm 0.6$ \\
\hline Conductivity $\left(\mu \mathrm{S} . \mathrm{cm}^{-1}\right)$ & $68.2 \pm 6.8$ & $68 \pm 6.4$ & $68.1 \pm 6.5$ & $68 \pm 7$ \\
\hline \multicolumn{5}{|l|}{ True Colour $(\mathrm{Hu})$} \\
\hline Mean \pm SD & $244 \pm 24$ & $236 \pm 35$ & \multicolumn{2}{|c|}{$244 \pm 25 \bigcirc 232 \pm 45$} \\
\hline Removal (\%) & $1.3 \pm 2$ & $3.4 \pm 8$ & $0.9 \pm 1.9$ & $5.9 \pm 14$ \\
\hline DGF + HSSF removal (\%) & \multicolumn{2}{|c|}{$4.6 \pm 8.3$} & \multicolumn{2}{|c|}{$6.6 \pm 14.4$} \\
\hline \multicolumn{5}{|l|}{ Apparent Colour $(\mathrm{Hu})$} \\
\hline Mean \pm SD & $306 \pm 32$ & $286 \pm 35$ & $311 \pm 34$ & $285 \pm 42$ \\
\hline Removal (\%) & $10.3 \pm 4.1$ & $6.5=$ & $8.6 \pm 3.8$ & $8.7 \pm 8.5$ \\
\hline DGF + HSSF removal (\%) & \multicolumn{2}{|c|}{$16.2 \pm 5.7$} & \multicolumn{2}{|c|}{$16.6 \pm 8.4$} \\
\hline \multicolumn{5}{|l|}{ Turbidity (NTU) } \\
\hline Mean \pm SD & $18.1 \pm 3.5$ & $13.8 \pm 3$ & $19.2 \pm 4$ & $14.1 \pm 3.3$ \\
\hline Removal (\%) & $53.6 \pm 11.7$ & $23.2 \pm 9.8$ & $50.7 \pm 12.2$ & $26 \pm 11.3$ \\
\hline DGF + HSSF removal (\%) & \multicolumn{2}{|c|}{$64.6 \pm 8.9$} & \multicolumn{2}{|c|}{$64 \pm 9.1$} \\
\hline \multicolumn{5}{|l|}{ Absorbance $(\lambda 254 \mathrm{~nm})$} \\
\hline Mean \pm SD & $0.550 \pm$ & $0.537 \pm$ & $0.551 \pm$ & $0.541 \pm$ \\
\hline Reduction (\%) & $0 \pm 2.1$ & $1.3 \pm 2.9$ & $0.1 \pm 1.9$ & $0.5 \pm 2.6$ \\
\hline DGF + HSSF removal (\%) & \multicolumn{2}{|c|}{$1.2 \pm 2.9$} & \multicolumn{2}{|c|}{$0.5 \pm 2.2$} \\
\hline \multicolumn{5}{|l|}{ TOC $\left(\mathrm{mg} \cdot \mathrm{L}^{-1}\right)$} \\
\hline Mean \pm SD & $7.76 \pm 0.76$ & $7.40 \pm 1.03$ & $7.76 \pm 0.82$ & $7.36 \pm 1.37$ \\
\hline Removal (\%) & $-0,3 \pm 4.6$ & $5.8 \pm 7.5$ & $0.7 \pm 3.2$ & $5.4 \pm 12.5$ \\
\hline DGF + HSSF removal (\%) & \multicolumn{2}{|c|}{$5.6 \pm 7.5$} & \multicolumn{2}{|c|}{$6.0 \pm 13.6$} \\
\hline \multicolumn{5}{|l|}{ Particle size $(\mathrm{nm})$} \\
\hline Mean \pm SD & $583.1 \pm 81$ & $453.4 \pm 32.5$ & $595.8 \pm$ & $453.4 \pm 40.9$ \\
\hline Removal (\%) & $43.9 \pm 16.3$ & $21.1 \pm 10.7$ & $42.6 \pm 16.8$ & $23 \pm 10.2$ \\
\hline DGF + HSSF removal (\%) & \multicolumn{2}{|c|}{$56 \pm 13.2$} & \multicolumn{2}{|c|}{$55.9 \pm 14$} \\
\hline \multicolumn{5}{|l|}{ E. coli $\left(\mathrm{CFU} 100 \mathrm{ml}^{-1}\right)$} \\
\hline Geometric Mean & $1.8 \times 10^{4}$ & $1.7 \times 10^{3}$ & $2.6 \times 10^{4}$ & $3.0 \times 10^{3}$ \\
\hline Maximum value & $8.8 \times 10^{4}$ & $3.5 \times 10^{4}$ & $1.1 \times 10^{5}$ & $6.9 \times 10^{3}$ \\
\hline Minimum value & $5.0 \times 10^{2}$ & $5.6 \times 10^{1}$ & $1.0 \times 10^{3}$ & $1.0 \times 10^{2}$ \\
\hline Reduction $(\log )$ & $0.76 \pm 0.36$ & $1.02 \pm 0.49$ & $0.55 \pm 0.32$ & $0.98 \pm 0.71$ \\
\hline DGF + HSSF reduction & \multicolumn{2}{|c|}{$1.78 \pm 0.65$} & \multicolumn{2}{|c|}{$1.53 \pm 0.77$} \\
\hline
\end{tabular}

Note: $\mathrm{HMSF}=\mathrm{DGF}+\mathrm{HSSF}$ 
Sánchez et al. (2006). This might be related to the difficulty in slow sand filtration (SSF) in removing humic substances (Ellis and Wood, 1985). As apparent colour is influenced by turbidity and particle size, its removal was superior to the true colour (Table 2). There were no statistical differences among the filters in the removal of true and apparent colour. Turbidity removal mainly happened in DGF (about 50\%) and this confirms the role of this filter in protecting the HSSF against high turbidity, smoothed turbidity peaks and avoiding filter clogging (Galvis et al., 2002; Sánchez et al., 2006; Visscher, 2006). DGF1 and DGF2 provided higher turbidity removal than the findings obtained by Franco et al. (2012). Nevertheless, these authors found higher apparent colour removal.

HMSF turbidity removals were higher than those found by Galvis et al. (2002) and Sánchez et al. (2012). However, when HSSF1 and HSSF2 were evaluated, their efficiencies (around 64\%) were lower than that reported by Elliott et al. (2008), Faria Maciel and Sabogal-Paz (2018), Frank et al. (2014), Lynn et al. (2013), Murphy et al. (2010) and Young-Rojanschi and Madramootoo (2014), with turbidity removals in the range from 74 to $96 \%$. This divergence is associated to influent water characteristics between studies. There were no statistical differences between DGF, HSSF and HMSF in the study.

Influent water turbidity and filtered water during the operating time are shown in

Figure 3. Turbidity peaks for influent water happened when the parameter measurement occurred on the same day as the water preparation. HMSFs were able to maintain final turbidity around 20 NTU. However, filtered water did not meet the World Health 
307

studies used influent water with low turbidity (3.90-12.6 NTU), such as Ahmmed and Davra (2011), Elliot et al. (2008) and Stauber et al. (2006), achieving better HSSFs performances. Influent water prepared with kaolinite and low nutrient concentration may have influenced the filter efficiency in our study, as reported by Faria Maciel and SabogalPaz (2018) and Sabogal-Paz et al (2020).

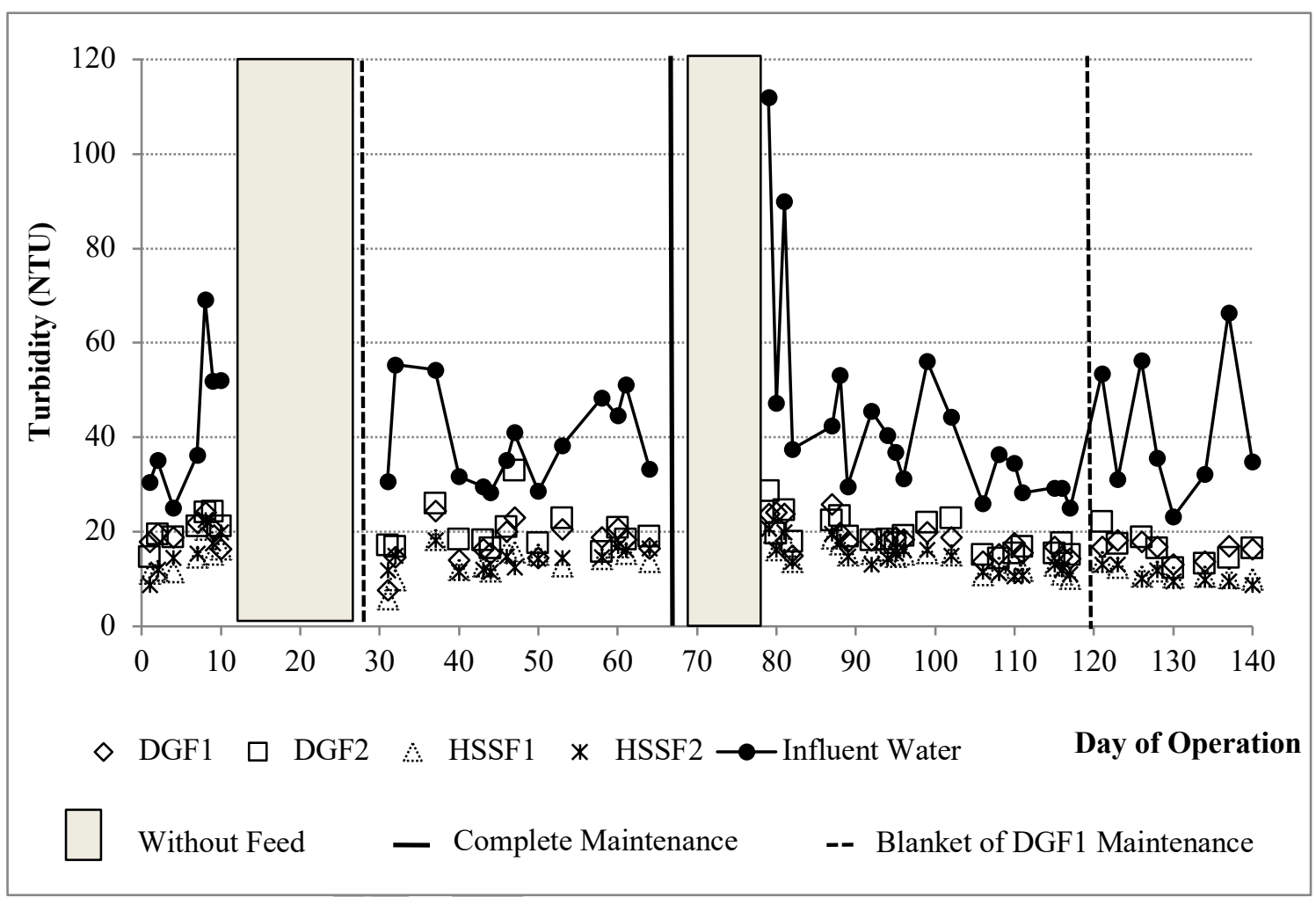

Figure 3 - Performance of DGFs and HSSFs in turbidity removal.

There was significant correlation between the influent water turbidity with both DGF efficiencies $(r=0.724$ and 0.783 , for DGF1 and DGF2, respectively). Similar findings were found by Franco et al. (2012) and Galvis et al. (2002), who reported that turbidity removal increased in the occurrence of peaks in raw water for DGF.

For all of the filters under study, turbidity removal did not correlate to the HMSFs' running time, when analysing the total period (140 days). However, there was significant correlation between the running time and turbidity removal during the period after 
maintenance of the non-woven blankets on the $64^{\text {th }}$ operation day, for DGF2 $(r=0.61)$ and HSSF1 $(r=0.57)$.

Particle size evaluation was important to understand how each filter in HMSF works. After the $53^{\text {rd }}$ day, after adding cysts and oocysts, the particle size of the influent water increased $(1205.8 \pm 296.3 \mathrm{~nm})$ and showed a statistical difference in relation to prior protozoan inoculum $(768 \pm 131.2 \mathrm{~nm})(p=0.0043)$. Higher particle size removal can be seen in the DGFs (Table 2), analogous to the turbidity results obtained. There were no statistic differences between the DGFs, HSSFs and HMSFs.

Filter ripening for the operation days was significantly correlated to a reduction in particle size for DGF2 $(r=0.41)$, HSSF1 $(r=0.50)$, HMSF1 $(r=0.55)$ and HMSF2 $(r=$ 0.53). This find may indicate that DGF removed the larger particles when compared with HSSFs and this might be due to the lower media depth present in the latter (Elliott et al., 2008).

There was no statistical difference between DGFs, HSSFs and the HMSFs (MannWhitney U test) when TOC was evaluated. HSSF efficiency in organic compound removal was lower (around 5\%) than the results found by Lynn et al. (2013) and Souza Freitas and Sabogal-Paz (2019). Nevertheless, the discrepancy in organic carbon removal may be related to compound composition (high or low biodegradability) and influent water characteristics (Campos et al., 2002; Modal et al., 2007). Low nutrient concentrations in the influent water can impair the biological activity in HSSFs (Lynn et al., 2013) and this situation may explain the lowest absorbance $(\lambda=254 \mathrm{~nm})$ and colour removals in our study, since only humic acid, kaolinite and E. coli were added to the influent water.

E. coli reduction during filter operation is shown for HMSF1 (Figure 4a) and for HMSF2 (Figure 4b). Among HSSFs there were no significant statistical differences; 
342 however, DGF1 showed a better performance than DGF2, according to the statistical test $343(p=0.018)$. HSSFs had greater efficiency than DGFs, among HSFF1 and DGF1 $(p=$ $3440.014)$, and HSSF2 and DGF2 $(p=0.023)$.
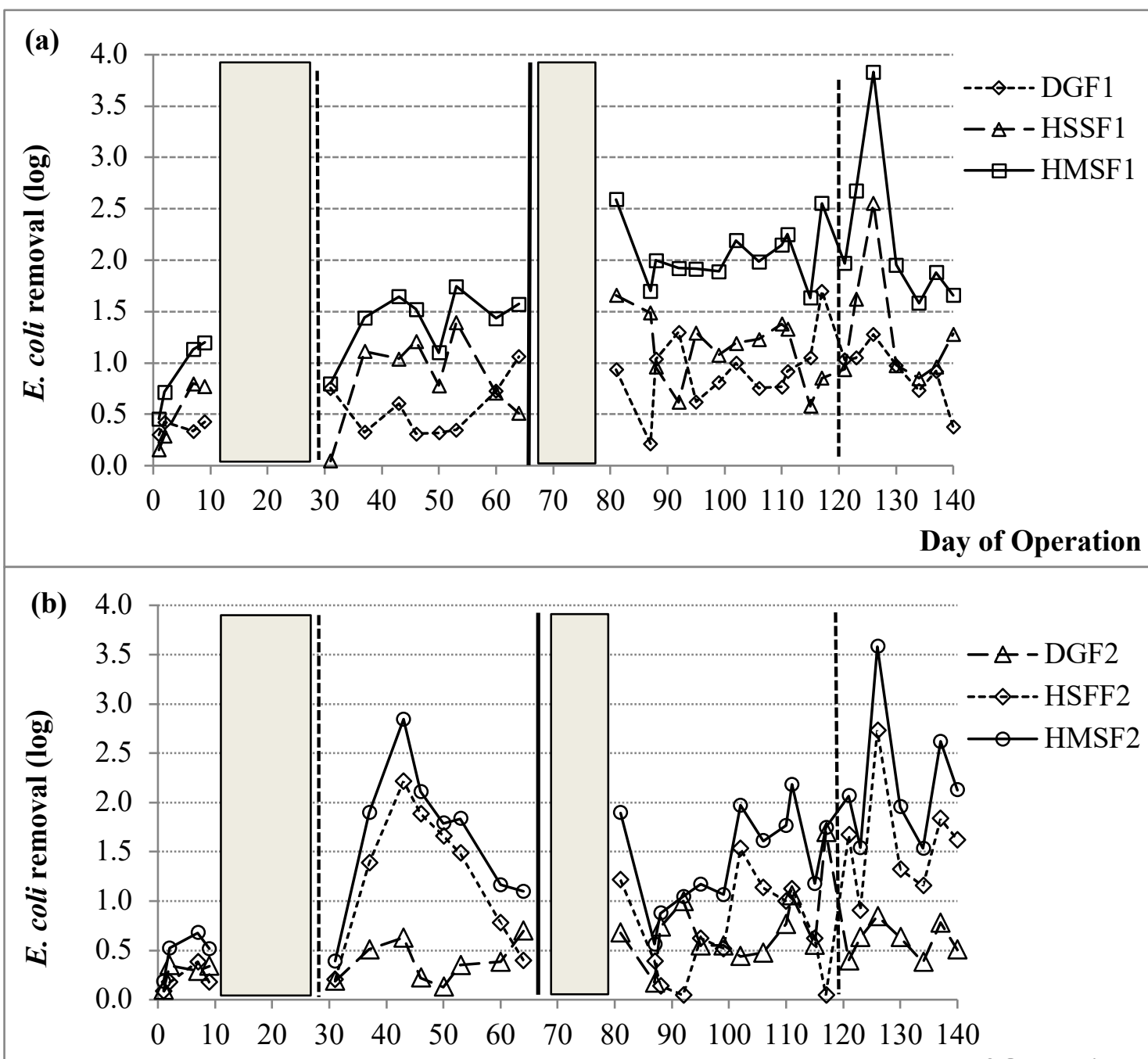

Without Feed

- Complete Maintenance

Blanket of DGF1 Maintenance

Figure 4 - E. coli reduction for DGFs and HSSFs

Young-Rojanschi and Madramootoo (2014) achieved removals up to 3.7 log and

Souza Freitas and Sabogal-Paz (2019) obtained reductions close to 3.0 log in HSSFs,

values higher than those obtained in our study (around $1.0 \mathrm{log}$, according to Table 2). On 
the other hand, HMSFs showed mean reductions close to that obtained by Galvis et al. (2002), between 1.9 to $4.0 \log$ for full-scale MSF systems composed by DGF followed by SSF.

E. coli reductions provided by DGF1, DGF2 and HSSF1 had a correlation with the operation days, due to filter ripening, and this finding matches the results obtained by Faria Maciel and Sabogal-Paz (2018) and Stauber et al. (2006). In addition, DGF ripening occurred through the progressive accumulation of particles and microorganisms as it happens in SSFs (Galvis et al., 2002).

Natural die-off can contribute to E. coli reductions due to stress, lack of nutrients, lack of oxygen, entrapment in sand pores and predation in the biological layer, as well as adsorption in the filter media (CAWST, 2012; Elliott et al., 2015).

Blanket cleaning in DGF1 negatively affected the HSSF1 performance (after the $31^{\text {st }}$ day) and in E. coli reduction DGF1 (after the $121^{\text {st }}$ ), with $\mathrm{r}=-0.77$ and $\mathrm{r}=-0.82$, respectively, according to the statistical study.

Complete HMSF maintenance, with blanket cleaning, DGFs drained and HSSF surface layer cleaning was done aiming to assess system resilience. Prior to that, there was no significant statistical difference between HMSFs for E. coli reduction, which did not happen after complete maintenance, with HMSF1 providing a better performance than that compared to HMSF2, according to the statistical test $(p=0.0015)$. HMSF1 showed nearly constant $E$. coli reduction of $2.0 \mathrm{log}$, after 10 days of complete maintenance, while HMSF2 presented greater instability (Figure 4). HMSFs obtained higher E. coli reduction at 126 days of operation, with $3.83 \log$ and $3.53 \log$ for HMSF1 and HMSF2, respectively. Faria Maciel and Sabogal-Paz (2018) reported a need for 140 days to reach maximum HSSF efficiency due to a low concentration of nutrients in the influent water that affected filter ripening. After complete HMSF maintenance both HMSFs required around 14 days 
to achieve progressive $E$. coli reduction and this fact was caused by their biofilm change, affecting HSSF efficiency.

A filter ripening period after cleaning must be carefully evaluated since the development of the biological layer is essential to improve microorganisms and turbidity removals in HSSFs (Ahammed and Davra, 2011; Bellamy et al., 1985; Napotnik et al., 2017).

Significant statistical results (Pearson test) were found by correlating physical variables with $E$. coli reduction in the following cases: i) HSSF2, with turbidity removal $(\mathrm{r}=0.41)$ and a reduction in particle size $(\mathrm{r}=0.46)$; and ii) after complete maintenance, in HSSF2 $(r=0.57)$ and HMSF2 $(r=0.55)$ with a decrease in particle size. However, turbidity and particle size in DGF output did not influence the $E$ coli reductions in HSSFs, according to the statistical test.

HMSFs were not fed for 19 days at the beginning of the operation and 14 days near the end of the operation to evaluate the HMSF performance after normal stops such as family holidays. Evidently, the HSSFs were affected and they took days to reach their efficiency and this phenomenon was also reported by Souza Freitas and Sabogal-Paz (2019). Filter ripening depends on the influent water quality, including nutrients and biodegradable carbon such as D-glucose (Modal et al., 2007) and natural coagulant (Souza Freitas and Sabogal-Paz, 2019). However, biological layer formation can reach days or even months to get completely formed. Therefore, the rapid ripening of the filter should be better studied to avoid abandoning technology in rural areas when it presents poor performance in some periods.

\subsection{Protozoan tests}



was statistically higher that Cryptosporidium spp. oocysts for both methods. The relative

404

405

406

407 408

\section{spp. oocysts}

\begin{tabular}{|c|c|c|c|}
\hline Methods & \multicolumn{2}{|c|}{ Membrane Filtration + IFA } & Triple Centrifugation + IMS + \\
\hline Protozoa & Cysts & Oocysts & Oocysts \\
\hline $\begin{array}{l}\text { Cysts and } \\
\text { oocysts } \\
\text { inoculated }\end{array}$ & $3329 \pm 149$ & $314 \pm 8$ & $307 \pm 12$ \\
\hline
\end{tabular}

\begin{tabular}{lcccc}
\hline & \multicolumn{3}{c}{ Recovery (\%) } & \\
\hline Tests & Cysts & Oocysts & Cysts & Oocysts \\
\hline Test 1 & 106 & 45 & 79 & 58 \\
\hline Test 2 & 90 & 29 & 79 & 36 \\
\hline Test 3 & 81 & 51 & 73 & 45 \\
\hline Test 4 & 95 & 45 & 87 & 47 \\
\hline Mean \pm RSD & $93 \pm 11.4$ & $42.2 \pm 22.5$ & $79.3 \pm 7.2$ & $46.7 \pm 19.2$
\end{tabular}

Note: RSD: relative standard deviation; IFA immunofluorescence assay; and IMS: immunomagnetic separation.

409

410

Giardia spp. cysts were detected in DGF and HSSF filtered water samples $(93 \%$

411 and 21\%, respectively). Cryptosporidium spp. oocysts were also found in filtered water

412 (71\% of DGFs and 43\% of HSSFs). Standard deviation and the average protozoa removal

413 are shown in Figure 5. 

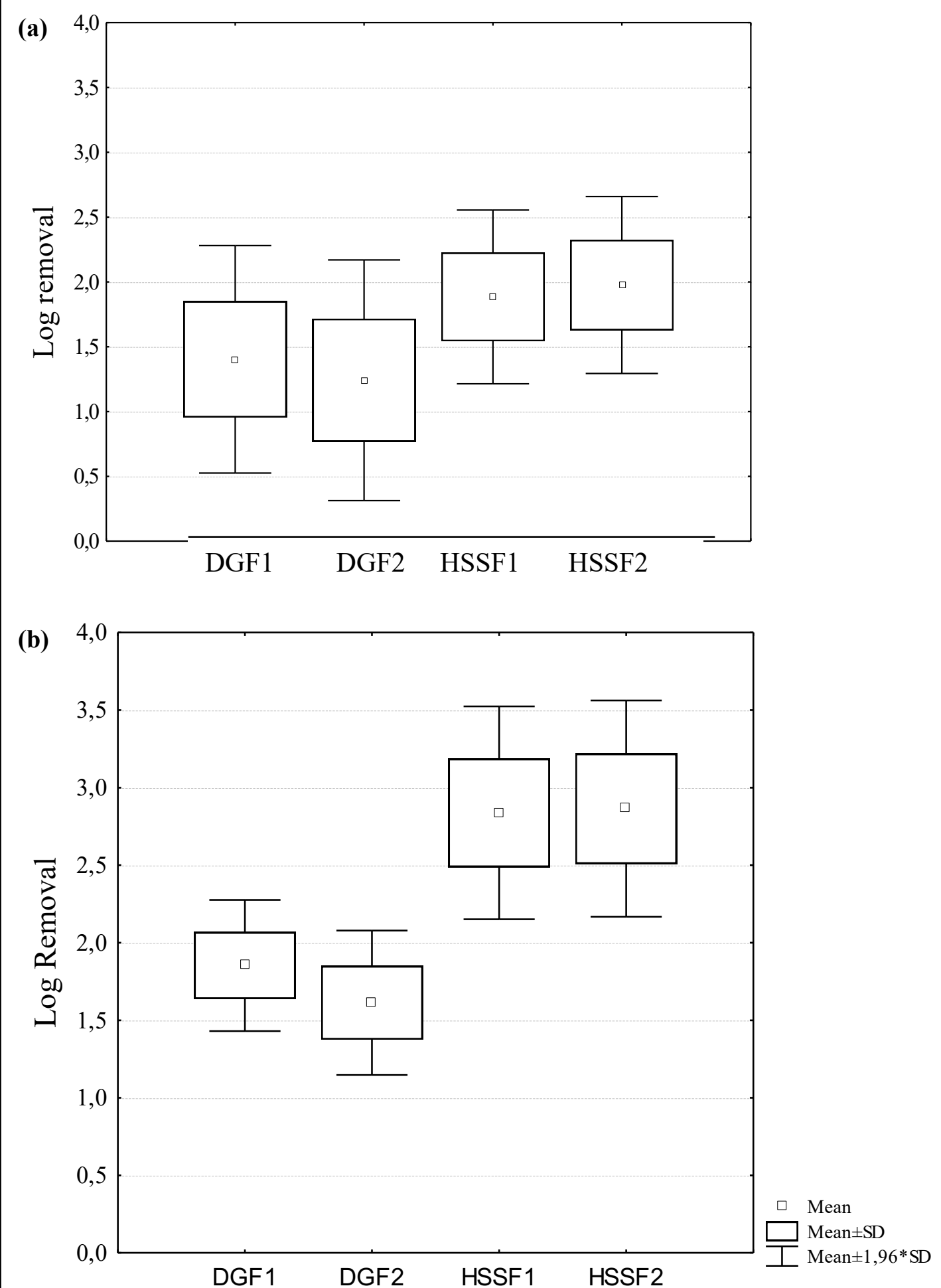

415 Figure 5 - DGF and HSSF efficiencies in Cryptosporidium spp. oocyst removal (a) and 416 Giardia spp. cyst removal (b). 

except for DGF2, that did not show a statistical difference. HSSFs were more efficient in removing both protozoa than DGFs, due to their low filtration rate and sand grain size. DGFs showed no difference in protozoa removal, according to statistical tests, with $1.40 \log \pm 0.45$ (DGF1) and $1.24 \log \pm 0.47$ (DGF2) for oocysts $(p=0.490)$ and 1.85 $\log \pm 0.22(\mathrm{DGF} 1)$ and $1.61 \log \pm 0.24(\mathrm{DGF} 2)$ for cysts $(p=0.096)$. There were also no statistical differences between HSSFs for protozoa removal as well, reaching $1.88 \log \pm$ 0.34 (HSSF1) and $1.98 \log \pm 0.35$ (HSSF2) for oocysts $(p=0.789)$. Giardia spp. cyst removal efficiency was also equal between the HSSFs with $2.84 \log \pm 0.35$ (HSSF1) and $2.86 \log \pm 0.36(\mathrm{HSSF} 2)(p=0.966)$. Our results are similar to those obtained by Bellamy et al. (1985) and Palmateer et al. (1999) and these authors emphasized the role of the biological layer on the filter performance. Sand grain size and sand bed depth are also important in protozoa removal (Hijnen et al., 2007). Our findings were better than those obtained by Fogel et al. (1993). Higher uniformity coefficient of the sand bed helps protozoan removal, especially oocysts, due to the inequality of the grain size of the sand, which generates winding water paths inside the filter.

Giardia cyst removals had a correlation with the filter operation time for DGF2 (r $=0.82)$ and $\operatorname{HSSF} 2(\mathrm{r}=0.77)$. Consequently, filter ripening as well as adherence and transport mechanisms are important for cyst and oocyst removals (Fogel et al., 1993; Tufenkji et al., 2006; Verma et al., 2017). HMSFs showed no statistical differences for cyst and oocyst removals. HMSF1 obtained $3.13 \log \pm 0.35$ and $2.16 \log \pm 0.35$ and HMSF2 obtained $3.15 \log \pm 0.36$ and $2.24 \log \pm 0.39$ for cysts $(p=0.898)$ and oocysts $(p=0.928)$, respectively. HMSF2 operation time had a relation with Giardia $(\mathrm{r}=0.78)$ and Cryptosporidium $(\mathrm{r}=0.84)$ 442 removals, according to the statistical test. 
444 water particle size, according to the statistical test. The analogous result happened when

445 E. coli reduction, turbidity removal and influent water turbidity were associated in the

446 statistical test.

447

\subsection{Sludge characteristics generated in HMSFs}

449

450

Sludge characteristics generated in HMSFs are shown in Tables 4 and 5. Complete

451

filter maintenance occurred on the $64^{\text {th }}$ and $140^{\text {th }}$ days and DGF1 blanket cleaning

452 occurred on the $121^{\text {st }}$ day (Figure 4).

453

454 Table 4 - DGF sludge characteristics

\begin{tabular}{|c|c|c|c|c|c|c|c|}
\hline \multirow[t]{2}{*}{ Parameter } & \multicolumn{3}{|c|}{ Non-woven blanket (DGF1) } & \multicolumn{2}{|c|}{$\begin{array}{c}\text { Drainage water } \\
\text { DGF1 }\end{array}$} & \multicolumn{2}{|c|}{$\begin{array}{c}\text { Drainage water } \\
\text { DGF2 }\end{array}$} \\
\hline & $\mathrm{I}$ & II & III & I & III & I & III \\
\hline $\begin{array}{l}\text { Apparent colour } \\
\text { (HU) }\end{array}$ & 2820 & 4020 & 3340 & 820 & 1510 & 655 & 568 \\
\hline Turbidity (NTU) & 10200 & 4130 & 3340 & 640 & 1140 & 421 & 468 \\
\hline $\mathrm{TS}\left(\mathrm{mg} \mathrm{L}^{-1}\right)$ & 10898 & 27280 & 27900 & 1084 & 1912 & 1214 & 842 \\
\hline TDS (mg L-1) & 1248 & 22670 & 23273 & 172 & 372 & 570 & 134 \\
\hline TSS (mg L-1) & 9650 & 4610 & 4627 & 912 & 1540 & 644 & 708 \\
\hline FSS $\left(\mathrm{mg} \mathrm{L}^{-1}\right)$ & 8038 & 3900 & 3909 & 786 & 1273 & 540 & 558 \\
\hline $\operatorname{VSS}\left(\mathrm{mg} \mathrm{L}^{-1}\right)$ & 1613 & 710 & 718 & 126 & 267 & 104 & 150 \\
\hline VSS/TSS ( $\%)$ & 17 & 15 & 16 & 14 & 17 & 16 & 21 \\
\hline $\begin{array}{l}\text { E. coli } \\
\left(\mathrm{CFU} \mathrm{mL}^{-1}\right)\end{array}$ & 5700 & 2600 & 280 & 330 & 550 & 330 & 640 \\
\hline $\begin{array}{l}\text { Giardia spp. } \\
\left(\text { cysts } \mathrm{g}^{-1}\right)\end{array}$ & 356 & 2551 & 2534 & 830 & 607 & 346 & 3302 \\
\hline $\begin{array}{l}\text { Cryptosporidium } \\
\text { spp. (oocysts g }{ }^{-1} \text { ) }\end{array}$ & 6 & 11 & 211 & nd & nd & nd & 24 \\
\hline
\end{tabular}

Notes: TS: total solids; TSS: total suspended solids; FSS: fixed suspended solids; VSS:

volatile suspended solids; nd: not detected. I and III: completed maintenance of the filters, after $64^{\text {th }}$ and $140^{\text {th }}$ days of operation; II: maintenance of the non-woven blanket from DGFs, after $121^{\text {st }}$ day of operation. 
Table 5- HSSF sludge characteristics

\begin{tabular}{|c|c|c|c|c|c|c|c|c|}
\hline \multirow{3}{*}{ Parameter } & \multicolumn{4}{|c|}{ Non-woven blanket } & \multicolumn{4}{|c|}{ Top sand layer } \\
\hline & \multicolumn{2}{|c|}{ HSSF1 } & \multicolumn{2}{|c|}{ HSSF2 } & \multicolumn{2}{|c|}{ HSSF1 } & \multicolumn{2}{|c|}{ HSSF2 } \\
\hline & $\mathrm{I}$ & III & $\mathrm{I}$ & III & $\mathrm{I}$ & III & $\mathrm{I}$ & III \\
\hline $\begin{array}{l}\text { Apparent colour } \\
\text { (HU) }\end{array}$ & 855 & 1060 & 965 & 1850 & 1090 & 3460 & 1340 & 4080 \\
\hline Turbidity (NTU) & 720 & 894 & 485 & 1160 & 590 & 2060 & 1060 & 1960 \\
\hline $\mathrm{TS}\left(\mathrm{mg} \mathrm{L}^{-1}\right)$ & 858 & 1160 & 746 & 1424 & 914 & 5000 & 1244 & 5480 \\
\hline TDS (mg L-1) & 268 & 274 & 266 & 244 & 277 & 2900 & 167 & 3380 \\
\hline $\mathrm{TSS}\left(\mathrm{mg} \mathrm{L}^{-1}\right)$ & 590 & 886 & 480 & 1180 & 637 & 2100 & 1077 & 2100 \\
\hline $\mathrm{FSS}\left(\mathrm{mg} \mathrm{L}^{-1}\right)$ & 425 & 705 & 347 & 880 & 510 & 1650 & 847 & 1630 \\
\hline $\operatorname{VSS}\left(\mathrm{mg} \mathrm{L}^{-1}\right)$ & 165 & 182 & 133 & 300 & 127 & 450 & 230 & 470 \\
\hline VSS/TSS (\%) & 28 & 21 & 28 & 25 & 20 & 21 & 21 & 22 \\
\hline $\begin{array}{l}\text { E. coli } \\
\left(\mathrm{CFU} \mathrm{mL} \mathrm{mL}^{-1}\right)\end{array}$ & 170 & 7 & 3 & 10 & 910 & & 1400 & 320 \\
\hline $\begin{array}{l}\text { Giardia spp. } \\
(\text { cysts g-1) }\end{array}$ & 163 & 483 & 509 & 2598 & 44 & & 241 & 2117 \\
\hline $\begin{array}{l}\text { Cryptosporidium } \\
\text { spp. (oocysts } \mathrm{g}^{-1} \text { ) }\end{array}$ & 70 & nd & 27 & 1025 & 22 & 20 & nd & 2263 \\
\hline
\end{tabular}

Notes: TS: total solids; TSS: total suspended solids; FSS: fixed suspended solids; VSS: volatile suspended solids; nd: not detected. I and III: completed maintenance of the filters, after $64^{\text {th }}$ and $140^{\text {th }}$ days of operation; II: maintenance of the non-woven blanket from DGFs, after $121^{\text {st }}$ day of operation.

457

458

Solid retention was observed mainly in the DGF1 blanket and inside the DGFs'

459

beds. In HSSFs, blanket and top sand layer showed high concentrations of total suspended

460 solids, apparent colour and turbidity. VSS concentration increase was found between

461 periods I and III for all the filters, except for DGF1 (between periods II and III) and this

462 can be a result of microorganism accumulation (i.e. bacteria, free-living protozoa, fungi)

463 in the schumutzdecke, blankets and inside the DGFs' beds, according to Figure 6. 


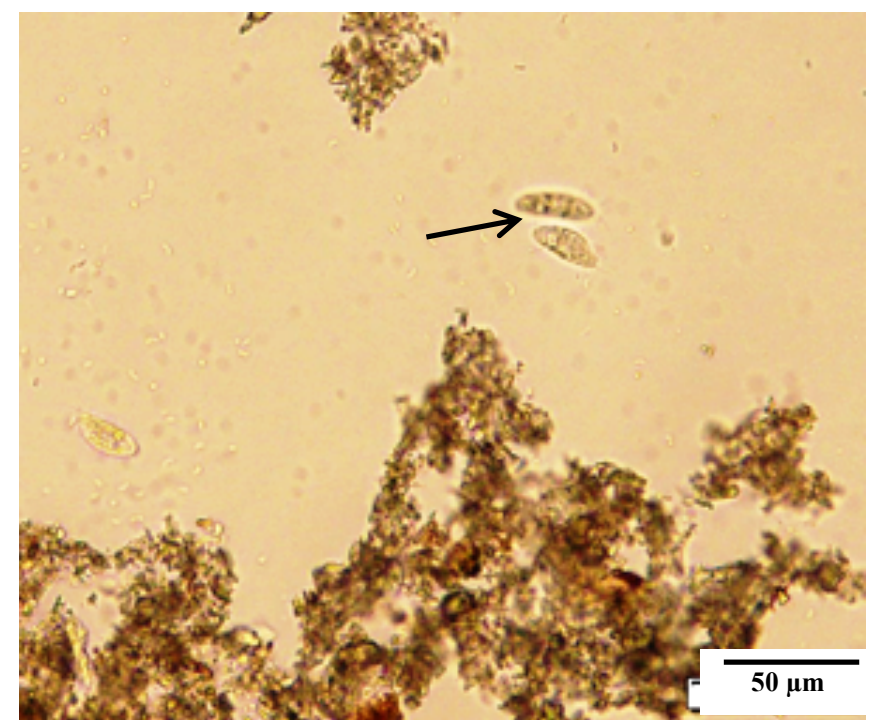

a) ciliate protozoa

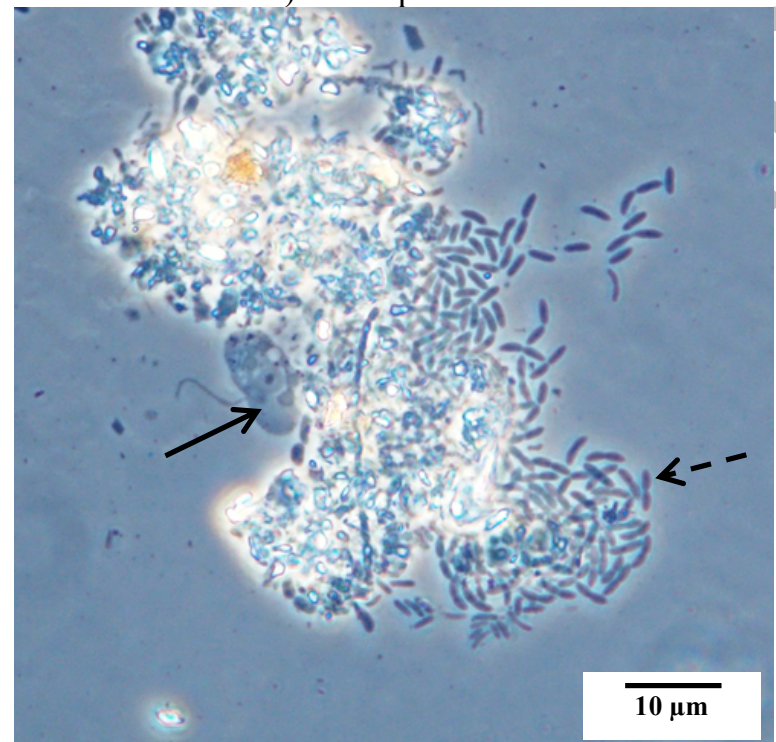

b) flagellate protozoa (continuous arrow) and bacteria (dashed arrow)

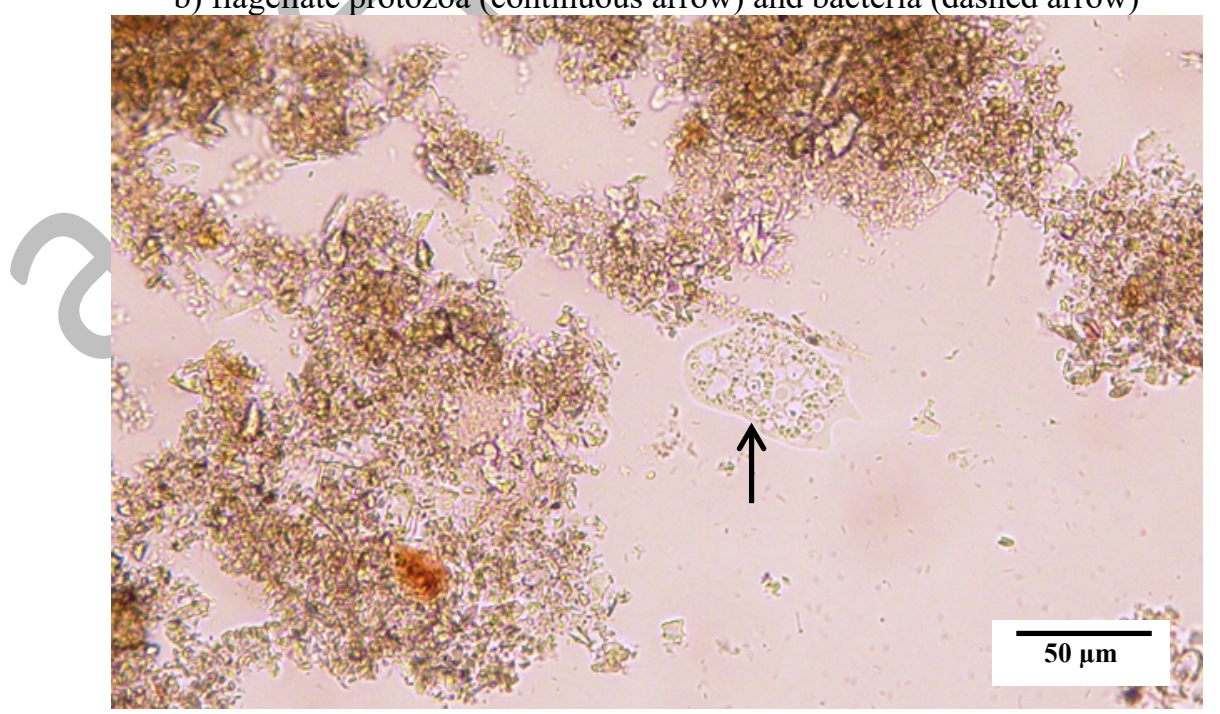

c) amoebae

466 Figure 6 - Microorganisms present in the blankets 
In the blankets, microorganisms morphologically similar to ciliate protozoa

468 (Figure 6a) were found, as well as flagellates (Figure $6 \mathrm{~b}$ - continuous arrow), amoebae

469 (Figure 6c) and a great amount of bacteria (i.e. cocci, bacilli, isolates and colonials, Figure $4706 \mathrm{~b}-$ dashed arrow) and some fungal hyphae. The number of microorganisms visualised 471 in the blankets followed the relation DGF1 $>$ HSSF2 $>$ HSSF1. The presence of 472 zooplankton as ciliate protozoa, amoebae and rotifers is associated with the greater oocyst removal at the top sand bed (Hijnen et al., 2007). Some authors identified rotifers (Bichai et al., 2014) and ciliate protozoa (Siqueira-Castro et al., 2016) as predators of Giardia cysts and Crypstosporidium oocysts.

The blankets, mainly in DGF1, showed potential for protozoa removal. The HSSF2 blanket presented a higher concentration of cysts and oocysts per gram compared with the HSSF1 blanket. This fact can be explained by the DGF1 blanket role in protozoa retention. However, this might also be interpreted as a warning for careful and safe planned handling of the blankets when conducting filter maintenance to avoid any unnecessary biological risk exposure of the filters' operator. SEM images for the blankets are shown in Figure 7. (figure 7d) and HSSF2 (Figure 7e) compared to its original state (Figure 7a). Figures 7c and $7 \mathrm{f}$ show a large amount of kaolinite in the DGF1 blanket and a possible oocyst retained in the HSSF2 blanket as well (arrow in Figure 7f).

A positive aspect of the blankets is to facilitate the filter maintenance, especially on a household scale (Souza Freitas and Sabogal-Paz, 2019; Terin and Sabogal-Paz, 2019). Blankets can also extend the filter run time since they protect the sand bed from particle deposition and the sand compaction (Faria Maciel and Sabogal-Paz, 2018; Modal 
492 requiring two blanket cleanings, besides the complete maintenance.

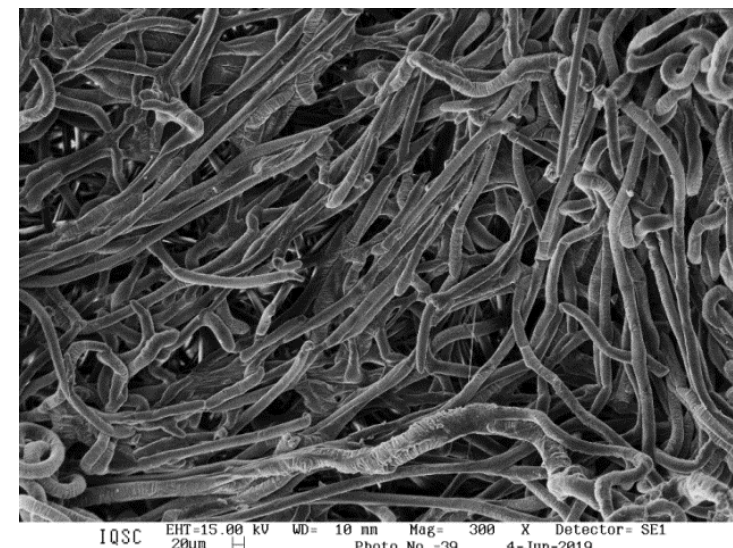

a)

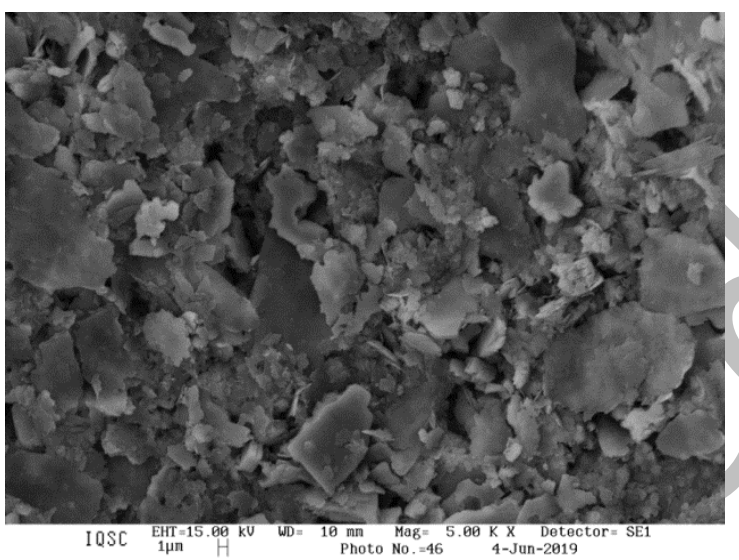

c)

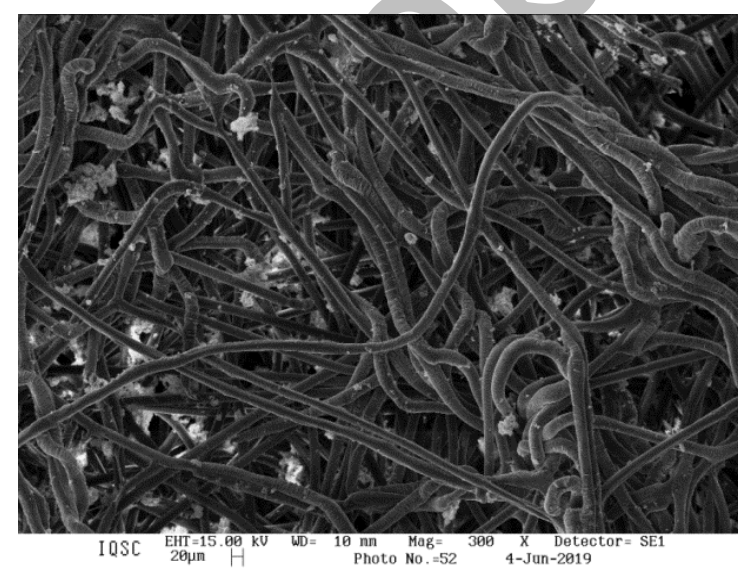

e)

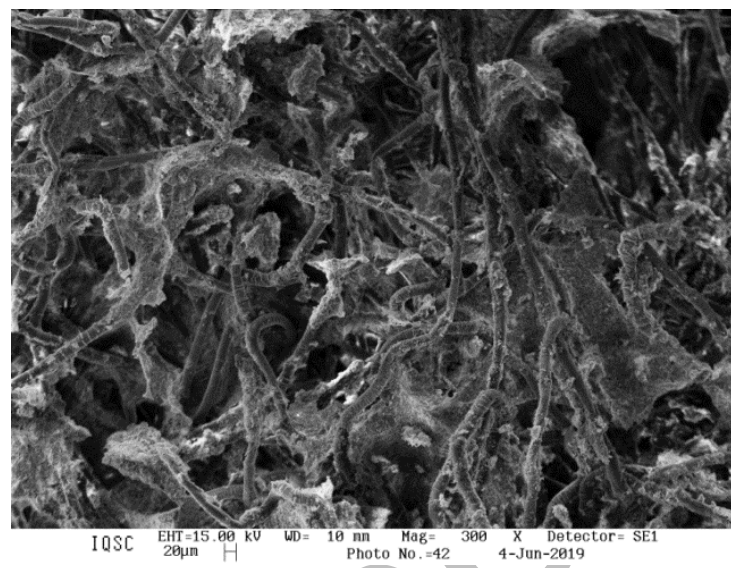

b)

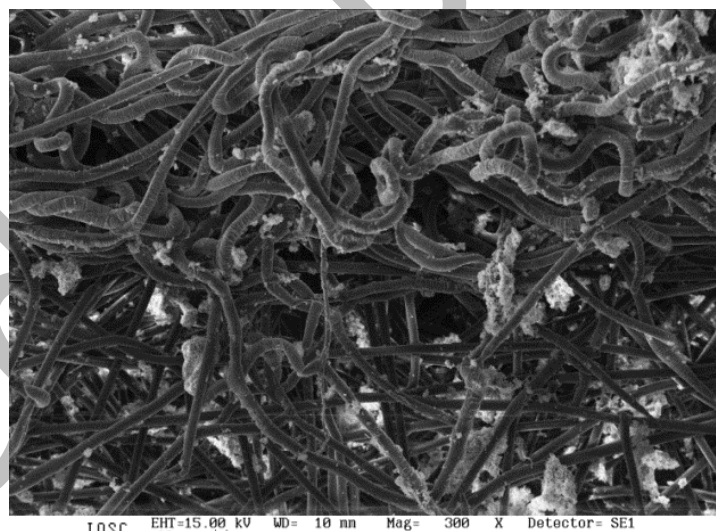

d)

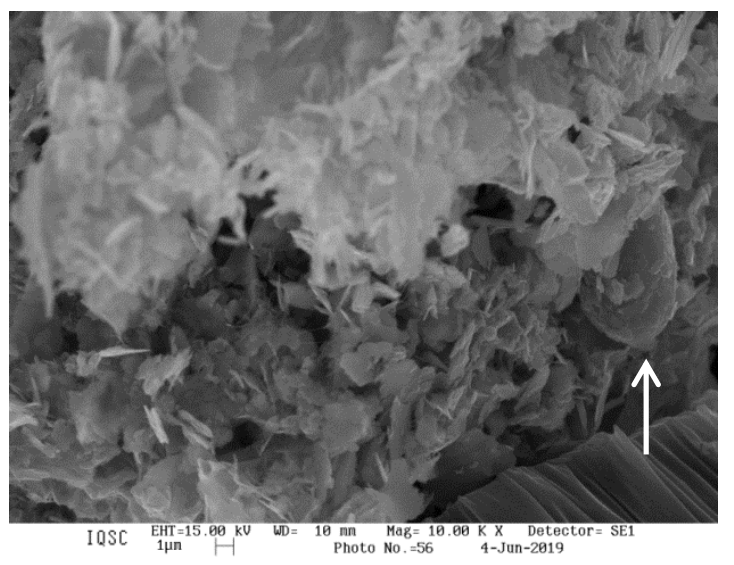

f)

493 Figure 7 - SEM images for blankets (a, b, d and e: $300 \mathrm{x}$; c: 5,000 x; f: 10,000 x). 
as a result of the blanket installed in DGF1 that retained part of these microorganisms,

497

498

499

500

501

502

503

504

505

506

507

508

510

511

512

513

514

515

516

517 This work was supported by the Global Challenges Research Fund (GCRF) UK

518 Research and Innovation (SAFEWATER; EPSRC Grant Reference EP/P032427/1).

\section{Conclusions}

HMSF removed turbidity $(>60 \%)$, E. coli $(>1.5 \log )$ and protozoa $(>2 \log )$ from influent water; but it was not efficient for colour removal. On the other hand, HMSF was not enough to generate drinking water according to World Health Organisation guidance. Consequently, further studies are needed to optimise the technology.

There were few correlations according to statistical tests between operating parameters. Nonetheless, operation time must be evaluated as a filter ripening parameter since it influenced E. coli and protozoa removals.

Non-woven blankets acted as a physical and microbiological barrier, improving $E$. coli and cyst and oocyst retention and turbidity removal.

HMSFs with a non-woven blanket is a clear example of the multi-barrier concept, in which there is more than one treatment stage to improve water quality, with gradual removal of particles and microorganisms.

\section{Acknowledgements}




\section{Statement}

Authors hereby declare previous originality check, no conflict of interest and open access to the repository of data used in this paper for scientific purposes.

\section{Supplementary Material}

Statistical analysis used in the study is provided.

\section{References}

Ahammed, M. M., Davra, K., 2011. Performance evaluation of biosand filter modified with iron oxide-coated sand for household treatment of drinking water. Desalination 276, 287-293. https://doi.org/10.1016/j.desal.2011.03.065

APHA, AWWA, WEF, 2012. Standard Methods for Examination of Water and Wastewater, twenty-second ed. American Public Health Association, Washington, IBSN 978-087553-013-0, p. 1360.

Baig, S.A., Mahmood, Q., Nawab, B., Shafqat, M. N., Pervez, A., 2011. Improvement of drinking water quality by using plant biomass through household biosand filter - A decentralized approach. Ecol. Eng. 37, 1842-1848.

Bellamy, W.D., Hendricks, D.W., Logsdon, G.S., 1985. Slow sand filtration: influences of selected process variables. J Am Water Works Association December, 62-66. https://doi.org/10.1002/j.1551-8833.1985.tb05659.x

Bichai, F., Dullemont, Y., Hijnen, W., Barbeau, B., 2014. Predation and transport of persistent pathogens in GAC and slow sand filters: A threat to drinking water safety? Water Res. 64, 296-308. http://dx.doi.org/10.1016/j.watres.2014.07.005 
545 Calixto, K. G., Sabogal-Paz, L. P., Pozzi, E., Campos, L. C. (2020). Ripening of $546 \quad$ household slow sand filter by adding fish Food. J Water Sanit Hyg De. 143. $547 \quad$ https://doi.org/10.2166/washdev.2020.143

548 Campos, L.C., Su, M.F.J., Graham, N.J.D., Smith, S.R., 2002. Biomass development in 549 slow sand filters. Water Res. 26, 4543-4551.

550 CAWST, 2012. Biosand Filter Construction Manual. Centre for Affordable Water and $551 \quad$ Sanitation Technology. Calgary, Canada.

552 Clasen, T.F., Alexander, K.T., Sinclair, D., Boisson, S., Peletz, R., Chang, H.H., 
570 Ellis, K.V., Wood, W.E., 1985. Slow sand filtration. Crit Rev Environ Control 15, $315-$

571

572

573

574

575

576

577

578

579

580

581

582

583

584

585

586

587

588

589

590

591

592

593

594 354. https://doi.org/10.1080/10643388509381736

Faria Maciel, P.M, Sabogal-Paz, L.P., 2018. Household slow sand filters with and without water level control: continuous and intermittent flow efficiencies, Environ Technol. https://doi.org/10.1080/09593330.2018.1515988

Fogel, D., Isaac-Renton, J., Guasparini, R., Moorehead, W., Ongerth, J., 1993. Removing Giardia and Cryptosporidium by slow sand filtration. J Am Water Works Association November, 77-84. https://doi.org/10.1002/j.15518833.1993.tb06105.x

Franco, M., Silva, G.K., Paterniani, J.E.S., 2012. Water treatment by multistage filtration system with natural coagulant from Moringa oleifera seeds. Eng. Agríc. 32, 989-997. http://dx.doi.org/10.1590/S0100-69162012000500018

Franco, R.M.B., Branco, N., Amaro, B.C.T., Cantusio Neto, R.; Fiuza, V.R.S., 2016. Cryptosporidium Species and Giardia Genotypes Detected in Surface Water Supply of Campinas, Southeast Brazil, by Molecular Methods. J Vet Med Res. 3, $1-7$.

Frank, T.E., Scheie, M.L., Cachro, V., Muñoz, A.S., 2014. The effect of increasing grain size in biosand water filters in combination with ultraviolet disinfection. $\mathrm{J}$ Water Sanit Hyg Dev. 4, 206-213. https://doi.org/10.2166/washdev.2013.171

Galvis, G.C., Latorre, J.M., Galvis, A.C., 2002. Multi-stage filtration technology. In: Small Community water supplies: technology, people and partnership. Eds. Smet, J.; van Wijk, C. Delft, The Netherlands, IRC International Water and Sanitation Centre. ISBN 90-6687-035-4, p. 585.

Hijnen, W.A.M., Dullemont, Y.J., Shijven, J.F., Hanzens-Brouwer, A.J., Rosielle, M., Medema, G., 2007. Removal and fate of Cryptosporidium parvum, Clostridium 
perfringens and small-sized centric diatoms (Stephanodiscus hantzschii) in slow

596

597

598

599

600

601

602

603

604

605

606

607

608

609

610

611

612

613

614

615

616

617

618 sand filters. Water Res. 41, 2151-2162.

https://doi.org/10.1016/j.watres.2007.01.056

Jenkins, M.W., Tiwari, S.K., Darby, J., 2011. Bacterial, viral and turbidity removal by intermittent slow sand filtration for household use in developing countries: Experimental investigation and modelling. Water Res. 54, 6227-6239. https://doi.org/10.1016/j.watres.2011.09.022

Levenspiel, O., 1999. Chemical Reaction Engineering, third ed. John Wiley \& Sons, Inc. Industrial \& Engineering Chemistry Research. https://doi.org/10.1021/ie990488g

Lynn, T.J., Wanjugi, P., Harwood, V.J., Ergas, S.J., 2013. Dynamic performance of biosand filters. J Am Water Works Association. http://dx.doi.org/10.5942/jawwa.2013.105.0116

Manz, D.H., 2007. Biosand water filter technology - household concrete design.

Medeiros, R.C., Daniel, L.A., 2018. Quantification and analysis of the viability of (oo)cysts of pathogenic protozoa in sewage sludge. Acta SciTechnol. 40, 1-6. http://dx.doi.org/10.4025/actascitechnol.v40i1.28709

Modal, P.K., Seth, R., Biswas, N., 2007. Performance evaluation of fabric aided slow sand filter in drinking water treatment. J Environ Eng Science 6, 703-712. http://dx.doi.org/10.1139/S07-019

Murphy, H.M., McBean, E.A., Farahbakhsh, K., 2010. A critical evaluation of two point-of-use water treatment technologies: can they provide water that meets WHO drinking water guidelines?. J Water Health 8, 611-630. https://doi.org/10.2166/wh.2010.156 
Napotnik, J.A., Baker, D., Jellison, K.L., 2017. Effect of sand bed depth and medium age on Escherichia coli and turbidity removal in biosand filters. Environ Sci Technol. 51, 3402-3409. https://doi.org/10.1021/acs.est.6b05113

Palmateer, G., Manz, D., Jurkovic, A., Mclnnis, R., Unger, S., Kwan, K.K., Dutka, B.J., 1999. Toxicant and parasite challenge of Manz intermittent slow sand filter. Environ Toxicol. 14, 217-225. https://doi.org/10.1002/(SICI)15227278(199905)14:2<217::AID-TOX2>3.0.CO;2-L

Perez, E., Cardosi, J., Coombes, Y., Devine, J., Grossman, A., Kullmann, C., Kumar, C. A., Mukherjee, N., Prakash, M., Robiarto, A., Setiawan, D., Singh, U., Wartono, D., 2012. What does it take to scale up rural sanitation? Water and Sanitation Program. The World Bank, p. 47.

Sabogal-Paz, L.P., Campos, L.C., Bogush, A., Canales, M., 2020. Household slow sand filters in intermittent and continuous flows to treat water containing low mineral ion concentrations and Bisphenol A. Sci Total Environ. 702, 135078-135091. https://doi.org/10.1016/j.scitotenv.2019.135078

Sánchez, L.D., Sánchez, A., Galvis, G., Latorre, J., 2006. Multi-Stage Filtration. Thematic Overview Paper 15. IRC Interantional Water and Sanitation Centre, CINARA, Universidad del Valle, p.62.

Sánchez, L.D., Marin, L.M., Visscher, J.T., Rietveld, L.C., 2012. Low-cost multi-stage filtration enhanced by coagulation-floculation in upflow gravel filtration. Drink Water Eng Sci. 5, 73-85. https://doi.org/10.5194/dwes-5-73-2012

Siqueira-Castro, I.C.V., Greinert-Goulart, J.A., Bonatti, T.B., Yamashiro, S., Franco, R.M.B., 2016. First report of predation of Giardia sp. cysts by ciliated protozoa and confirmation of predation of Cryptosporidium spp. oocysts by ciliate species. 

$6689-\mathrm{y}$

Speich, B., Croll, D., Furst, T., Utzinger, J., Keiser, J., 2016. Effect of sanitation and water treatment on intestinal protozoa infection: a systematic review and meta-

Souza Freitas, B.L., Sabogal-Paz, L., 2019. Pretreatment using Opuntia cochenillifera followed by household slow sand filters: technological alternatives for supplying isolated communities. Environ technol. 1-12. https://doi.org/10.1080/09593330.2019.1582700

Stauber, C.E., Elliott, M.A., Koksal, F., Ortiz, G.M., DiGiano, F.A., Sobsey, M.D., 2006. Characterisation of the biosand filter for E. coli reductions from household drinking water under controlled laboratory and field use conditions. Water Sci Technol. 54, 1-7. https://doi.org/10.2166/wst.2006.440

Terin, U.C., Sabogal-Paz, L.P., 2019. Microcysts aeruginosa and microcystin-LR removal by household slow sand filters operating in continuous and intermittent flows. Water Res. 150, 29-39. https://doi.org/10.1016/j.watres.2018.11.055

Tufenkji, N., Dixon, D.R., Considine, R., Drummond, C.J., 2006. Multi-scale Cryptosporidium/sand interactions in water treatment. Water Res. 40, 3315-3331. https://doi.org/10.1016/j.watres.2006.07.036

USEPA - US Environmental Protection Agency. 2012. Method 1623.1: Cryptosporidium and Giardia in water by filtration/IMS/FA. Office of Water. EPA/816/R-12/001. 
666 Verma, S., Davarey, A., Sharma, A., 2017. Slow sand filtration for water and

667

668

669

670

671

672

673

674

675

676

677

678

679

680

681

682

683

684

685

686

687

688

689 wastewater treatment - a review. Environ Technol Rev. 6, 47-58. https://doi.org/10.1080/21622515.2016.1278278

Visscher, J.T., 2006. Facilitating Community Water Supply treatment - From transferring filtration technology to multi-stakeholder learning. Thesis Wageningen Universiteit. ISBN: 90-8504-382-4, p. 254.

Wang, H., Narihiro, T., Straub, A.P., Pugh, C.R., Tamaki, H., Moor, J.F., Bradley, I.M., Kamagata, Y., Liu, W., Nguyen, T.H., 2014. MS2 bacteriphage reduction and microbial communities in biosand filters. Environ Sci Technol. 48, 6702-6709. https://doi.org/10.1021/es500494s

World Health Organization (WHO), 2003. Domestic water quantity, service, level and health. WHO Document Production Services, Geneva, Switzerland.

World Health Organization (WHO), 2011. Evaluating household water treatment options: health-based targets and microbiological performance specifications. Geneva, Switzerland.

World Health Organization (WHO), 2014. Harmonized testing protocol: technology non-specific. WHO international scheme to evaluate household water treatment technologies. World Health Organization, Geneva, Switzerland.

World Health Organization (WHO) and United Nations Children's Fund (UNICEF), 2017. Progress on Drinking Water, Sanitation and Hygiene: 2017 update and SDG Baselines. Geneva, Switzerland.

World Health Organization (WHO), 2017. Guidelines for Drinking Water Quality: fourth edition incorporating the first addendum. World Health Organization, Geneva, Switzerland. 
690 Young-Rojanschi, C., Madramootoo, C., 2014. Intermittent versus continuous operation

691 of biosand filters. Water Res. 49, 1-10.

692 https://doi.org/10.1016/j.watres.2013.11.011 